\title{
ЭКОЛОГИЯ
}

УДК 581.5

doi: $10.17223 / 19988591 / 51 / 8$

\author{
Р.Х. Гиниятуллин ${ }^{1}$, 3.Б. Бактыбаева ${ }^{2}$ \\ ${ }^{1}$ Уфимский Институт биологии - обособленное структурное подразделение \\ Уфимского федерального исследовательского иентра РАН, г. Уфа, Россия \\ ${ }^{2}$ Уфимский научно-исследовательский институт медицинь \\ труда и экологии человека, г. Уфа, Россия
}

\section{Особенности накопления $\mathrm{Cd}$ и $\mathrm{Ni}$ лиственницей Сукачева (Larix sukaczewii Dyl.) в условиях техногенеза}

\author{
Работа выполнена в рамках государственного задания Минобрнауки \\ России № 075-00326-19-00 по теме АAАA-А18-118022190102-3. \\ Часть результатов получена с использованием оборудования \\ Регионального центра коллективного пользования «Агидель».
}

\begin{abstract}
Изучены особенности накопления $и$ распределения тяжелых металлов (кадмия и никеля) в надземных и подземных органах лиственницы Сукачева (Larix sukaczewii Dyl.) в условиях Стерлитамакского промылиленного иентра. Проведена сравнительная оценка относительного жсизенного состояния санитарнозашитных лиственничных лесонасаждений, расположенных в непосредственной близости от промышленной зоны города и в зоне условного контроля. Выявлено, что повышение концентрации металлов в почве приводит $\kappa$ увеличению их содержания в хвое, ветвях и корневой системе деревьев. В подземной части никель в основном аккумулируется поглощающими корнями, кадмий поглощающими и полускелетными. В надземной части конщентрация металлов в ветвях выше, чем в хвое. В то же время у здоровых деревьев сохранена барьерная функиия корневой системы, препятствующая избыточному поступлению поллютантов в надземные органы, у ослабленных деревьев барьерная функиия снижена. Изучение корненасыщенности почвенного покрова показало, что в зоне условного контроля на глубине 0-20 см масса поглощающих корней достигает

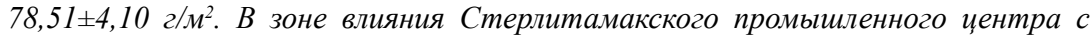
повышением уровня тяжелых металлов в грунте происходит снижение доли поглощающих корней: у здоровых деревьев в 2 раза, у ослабленных - в 2-3 раза. На загрязненном участке наблюдаются внешние признаки угнетения деревьев: уменьшение густоты кроны на 20-25\%, увеличение количества мертвых ветвей до 25-30\%, поражение ассимиляционного аппарата хлорозами и некрозами до 15\%. Деревья, относящиеся к категории «ослабленные», составляют 55\% древостоя, а сухостой достигает $10 \%$.
\end{abstract}

Ключевые слова: тяжелье металль; санитарно-защитные лесонасаждения; относительное жизненное состояние древостоя; корненасыщенность почвы; Стерлитамакский промышленный центр; Предуралье. 


\section{Введение}

Среди загрязнителей промышленно развитых территорий особую опасность представляют тяжелые металлы (ТМ), так как в отличие от органических веществ они не подвергаются процессам разложения и легко переходят из одной среды в другую [1]. В составе выбросов ТМ способны рассеиваться на десятки километров и затем оседать, загрязняя почвенный покров. Дальнейшая миграция и перераспределение поллютантов в компонентах экосистем зависят от многих природных факторов, а также от интенсивности техногенеза. С повышением концентрации тяжелые металлы становятся токсичными для живых организмов $[2,3]$.

Одним из эффективных способов оздоровления окружающей среды загрязненных территорий является создание санитарно-защитных лесонасаждений, которые способствуют осаждению аэрополлютантов, а также поглощению токсикантов из почвы. Однако выполнение в течение длительного времени функции фитофильтра негативно сказывается на жизненном состоянии самих деревьев, вследствие чего могут наблюдаться такие явления, как замедление их роста и развития, преждевременное частичное усыхание, а также общее ослабление всего древостоя [4-7]. Результаты исследований по изучению поглотительной способности разных видов древесных растений и их реакции на действие ТМ позволяют выявлять перспективные виды-фиторемедиаторы [8-12], а также прогнозировать устойчивость лесных насаждений и проектировать лесохозяйственные мероприятия [13-16].

На территории Республики Башкортостан во второй половине XX столетия при формировании санитарно-защитных зон вокруг городов широко применялась лиственница Сукачева (Larix sukaczewii Dyl.) [17, 18]. Популярность данного представителя семейства Pinaceae Lindl. связана с такими характеристиками, как быстрый рост и морозоустойчивость. В то же время адаптационные возможности вида к повышенному содержанию ТМ в окружающей среде остаются малоизученными. Недостаточно сведений и по аккумуляции металлов в различных органах лиственницы Сукачева.

Цель данного исследования - выявить особенности накопления и распределения тяжелых металлов ( $\mathrm{Cd}$ и $\mathrm{Ni})$ лиственницей Сукачева и оценить относительное жизненное состояние древостоя в условиях Стерлитамакского промышленного центра.

\section{Материалы и методики исследования}

Район исследования расположен на стыке Предбельского лесостепного и Предуральского степного района. Средняя годовая температура воздуха составляет $3,2{ }^{\circ} \mathrm{C}$, среднее годовое количество осадков - 498,9 мм. Преимущественное направление ветра - южное (35\%). Почвообразующими породами служат делювиальные и аллювиально-делювиальные отложения. В почвенном покрове преобладают черноземы типичные и выщелоченные $[19,20]$. 
Город Стерлитамак (5338'00"N, 555'00"Е) характеризуется относительно высокой техногенной нагрузкой, свойственной территориям с развитой химической и нефтеперерабатывающей промышленностью. Крупные производственные объекты сосредоточены в северной части города. На сегодняшний день загрязнение атмосферного воздуха и почвенного покрова в Стерлитамаке, в первую очередь, связано с работой таких предприятий, как «Башкирская содовая компания», «Синтез-Каучук», «Стерлитамакский нефтехимический завод», «ХайдельбергЦементРус». Кроме того, вклад в загрязнение компонентов окружающей среды вносят предприятия машиностроения, электроэнергетики и автотранспорта. За последние 20 лет общий объем валовых выбросов по городу варьировал в пределах 54-119 тыс. тон в год. При этом наиболее высокие показатели (более 100 тыс. т в год) приходились на 2000 г. и период с 2006 по 2011 г. Начиная с 2012 г. наблюдается постепенное снижение объема валовых выбросов. Несмотря на это, плотность выбросов загрязняющих веществ от стационарных и передвижных источников на территории Стерлитамака остается самой высокой среди городов республики и в 2018 г. составила 5,63 т в расчете на 1 га. Количество твердых загрязняющих веществ, выброшенных в атмосферу, составило 1,88 тыс. т/год [21]. Специфика производственных процессов обусловливает высокое содержание в выбросах оксида кальция (до 0,56 тыс. т/год) и неорганической пыли (до 0,50 тыс. т/год). Периодически регистрируются превышения предельно допустимых концентраций в 3-4 раза по бенз(а)пирену, формальдегиду, этилбензолу, аммиаку, сероводороду, ксилолам, взвешенным веществам; в 2-3 раза - по хлориду водорода, оксиду углерода, оксиду азота, диоксиду азота, диоксиду серы, фенолу. Как известно, в результате функционирования предприятий нефтехимической отрасли в воздушный бассейн поступает более 200 специфических поллютантов, среди которых особо опасными считаются канцерогены. К их числу относятся в том числе кадмий и никель [22]. Согласно санитарно-гигиеническому мониторингу, многолетние показатели концентрации никеля в атмосферном воздухе г. Стерлитамак находятся в пределах нормы. Кадмий не входит в перечень определяемых загрязнителей. В почвенном покрове на территории города валовые формы никеля, кадмия, свинца, меди и цинка превышают фоновые концентрации в 1,2-2,5 раза [23].

Санитарно-защитные полосы с участием лиственницы Сукачева расположены в северной и южной части города. При создании лиственничных культур использован однородный в генетическом отношении посадочный материал из питомника. Исследования проведены в 2007-2018 гг. на двух постоянных пробных площадях (ППП). Закладка и описание пробных площадей выполнены по общепринятым методикам [24, 25]. ППП заложены на однородных по почвенно-эдафическим условиям участках в одновозрастных (около 55 лет) и чистых по составу древостоях. ППП № 1 размером $20 \times 50$ м в 1-2 км от источников нефтехимического и химического загрязнения Стерлитамакского промышленного центра (рис. 1). Общая длина санитарно-за- 
щитного лиственничного лесонасаждения - 500 м, ширина - 30 м. ППП № 2 размером $18 \times 50$ м - в зоне условного контроля (25 км от промышленной зоны). Общая длина данного санитарно-защитного лесонасаждения -800 м, ширина - 30 м. Уровень залегания грунтовых вод на исследуемых участках - высокий (1,2 м) [19].

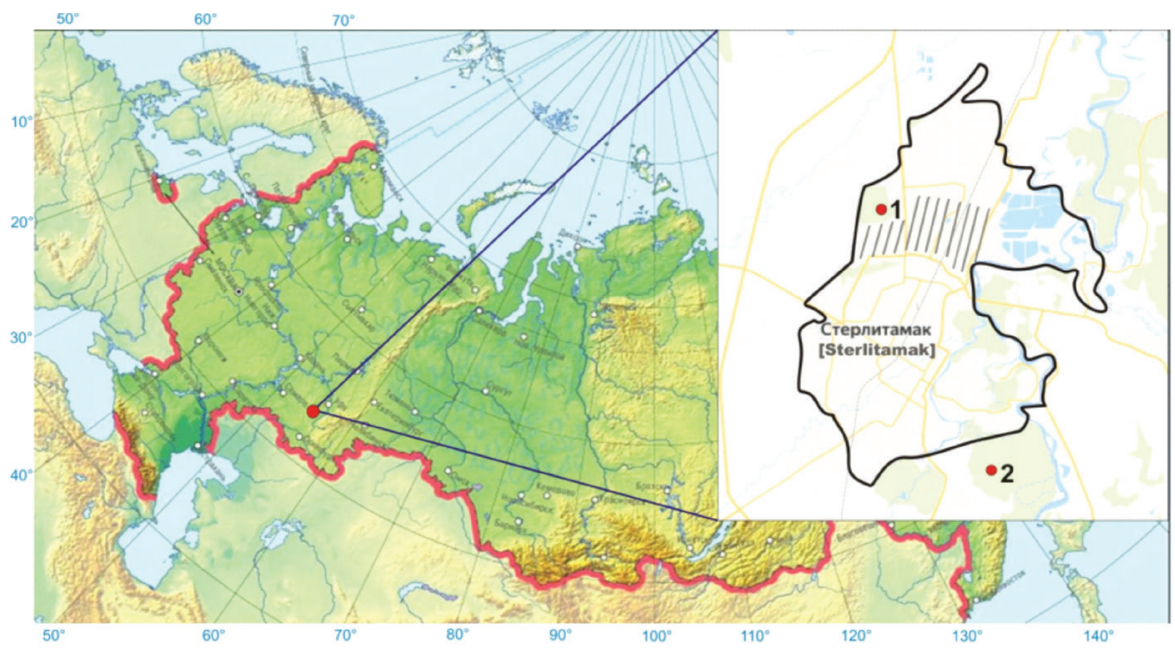

Рис. 1. Местоположение постоянных пробных площадей на территории г. Стерлитамак.

Условные обозначения: 1 - постоянная пробная площадь в условиях промышленного центра; 2 - постоянная пробная площадь в зоне условного контроля;

[Fig. 1. Location of permanent trial plots in the city of Sterlitamak.

Legend: 1 - Permanent trial plot in the industrial center; 2 - Permanent trial plot in the area of conditional control;

Для определения лесотаксационных параметров лиственничных насаждений применен метод сплошных перечетов на ППП. В течение 12 лет в эксперименте задействовали по 110 модельных экземпляров на участок. У каждой лиственницы измеряли высоту с помощью высотомера «Haglof Electronic Clinometer» (Швеция), а также диаметр ствола на высоте 1,3 м. Средний диаметр элемента леса определяли через среднюю площадь сечения: сумма площадей сечений модельных экземпляров поделена на их общее количество. Средняя высота древостоя установлена по графику высот для среднего диаметра. График высот построен на основании замеров у 20 деревьев. Краткая таксационная характеристика изученных насаждений представлена в табл. 1.

Относительное жизненное состояние деревьев определяли по методике В.А. Алексеева [26], согласно которой проведена визуальная оценка таких диагностических признаков как густота кроны (в \% от нормальной густоты), наличие на стволе мертвых сучьев (в \% от общего количества сучьев на стволе), степень повреждения хвои токсикантами, патогенами и насекомы- 
ми (средняя площадь в \% от площади хвои). Категория жизненного состояния отдельного дерева определена по вспомогательной таблице (табл. 2).

Таблица 1 [Table 1] Краткая таксационная характеристика насаждений лиственницы Сукачева (Larix sukaczewii Dyl.) в условиях промышленного центра и в зоне условного контроля

[Brief taxation characteristics of Larix sukaczewii Dyl. plantations

in the industrial center and in the area of conditional control] $(M \pm S D)$

\begin{tabular}{|c|c|c|c|c|}
\hline $\begin{array}{c}\text { Состав } \\
\text { [Stand composition] }\end{array}$ & $\begin{array}{c}\text { Класс возраста } \\
\text { [Age class] }\end{array}$ & $\begin{array}{l}\text { Диаметр, см } \\
\text { [Diameter, cm] }\end{array}$ & $\begin{array}{l}\text { Высота, м } \\
\text { [Height, m] }\end{array}$ & $\begin{array}{c}\text { Класс } \\
\text { бонитета } \\
\text { [Quality class] }\end{array}$ \\
\hline \multicolumn{5}{|c|}{ В условиях промышленного центра [In the industrial center] } \\
\hline $10 \mathrm{Ls}$ & III & $17,60 \pm 0,4$ & $20,90 \pm 0,6$ & $\mathrm{I}$ \\
\hline \multicolumn{5}{|c|}{ В зоне условного контроля [In the area of conditional control] } \\
\hline $10 \mathrm{Ls}$ & III & $20,80 \pm 0,8$ & $23,10 \pm 1,0$ & $\mathrm{I}$ \\
\hline
\end{tabular}

Примечание [Note]: Ls - Larix sukaczewii

Таблица 2 [Table 2]

Вспомогательная таблица для определения категорий деревьев (Алексеев, 1990)

[Auxiliary table for determining categories of trees (Alekseev, 1990)]

\begin{tabular}{|l|c|c|c|}
\hline \multirow{2}{*}{$\begin{array}{c}\text { Категория дерева } \\
\text { [Category] }\end{array}$} & \multicolumn{3}{|c|}{ Диагностические признаки [Diagnostic features] } \\
\cline { 2 - 4 } & $\begin{array}{l}\text { Густота кроны } \\
\text { [Crown density], \% }\end{array}$ & $\begin{array}{c}\text { Наличие мертвых } \\
\text { сучьев } \\
\text { [Dry branches], \% }\end{array}$ & $\begin{array}{c}\text { Степень повреж- } \\
\text { дения листьев } \\
\text { [Leaf damage } \\
\text { degree], \% }\end{array}$ \\
\hline Здоровое [Healthy] & $86-100$ & $0-15$ & $0-10$ \\
\hline Ослабленное [Weakened] & $56-85$ & $16-45$ & $11-45$ \\
\hline $\begin{array}{l}\text { Сильно ослабленное } \\
\text { [Strongly weakened] }\end{array}$ & $21-55$ & $46-70$ & $46-65$ \\
\hline Oтмирающеe [Dying] & $1-20$ & $71-99$ & $71-100$ \\
\hline Сухое [Dead] & 0 & 100 & $\begin{array}{c}\text { Нет листьев } \\
\text { [No leaves] }\end{array}$ \\
\hline
\end{tabular}

После суммирования количества деревьев по категориям проведена оценка относительного жизненного состояния всего насаждения по следующей формуле:

$$
L_{N}=\frac{100 \cdot n_{1}+70 \cdot n_{2}+40 \cdot n_{3}+5 \cdot n_{4}}{N},
$$

где $L_{N}$ - относительное жизненное состояние древостоя, рассчитанное по числу деревьев; $n_{1}$ - число здоровых деревьев на пробной площади; $n_{2}, n_{3}$, $n_{4}$ - то же для ослабленных, сильно ослабленных и отмирающих деревьев соответственно; 100, 70, 40, 5 - коэффициенты, выражающие (в процентах) жизненное состояние здоровых, ослабленных, сильно ослабленных и отмирающих деревьев; $N$ - общее число деревьев на пробной площади (включая сухостой).

При показателе от 100 до 80\% древостой оценивался как «здоровый», 79-50\% - «ослабленный», 49-20\% - «сильно ослабленный», 19\% и ниже «полностью разрушенный». 
Исследование насыщенности почвы поглощающими корнями проведено методом монолита [27]. Траншеи (почвенные разрезы) на пробных площадях заложены перпендикулярно направлению роста горизонтальных корней. В связи с тем, что расстояние между рядами деревьев составляло 1,7 м, а между деревьями в ряду 2,0 м, почвенные разрезы расположены на удалении 0,7 м от ствола. Все почвенные разрезы имели одинаковые размеры - $1 \times 1$ м. Глубина траншеи -1 м. В каждой траншее заложено по 10 почвенных монолитов размером $10 \times 10 \times 10 \mathrm{~cm}$. Выборка корней при помощи пинцета с последующей отмывкой водой. Дробность фракций: менее 1 мм в диаметре (поглощающие корни), 1-3 мм (полускелетные корни), более 3 мм (скелетные корни). Масса поглощающих корней определена в воздушно-сухом состоянии на электронных лабораторных весах «ВЛТЭ-150» (Россия). Корненасыщенность почвы определена на единицу площади горизонтальной поверхности $\left(г / \mathrm{M}^{2}\right)$.

Для изучения содержания металлов ежегодно в течение вегетационного сезона (июнь-август) проводили многократный повторный отбор проб хвои, ветвей и корней. Пробы отбирали после пятидневного сухого бездождевого периода. Образцы хвои и ветвей собирали из верхней, средней и нижней части кроны деревьев со стороны источника загрязнения. Далее из точечных проб одного дерева составлялась усредненная проба. Отмывку хвои и веток не проводили [28]. В лабораторных условиях растительные образцы высушивали до воздушно-сухого состояния. В дальнейшем пробы хвои, веток и корней тщательно измельчали в агатовых ступках и с помощью мельницы.

На тех же пробных площадях одновременно с растительными отбирали почвенные пробы с глубины 0-20 см. Вокруг одного дерева пробы отбирали в 5 повторностях - в точках, равноудаленных друг от друга, независимо от сторон света. Далее образцы объединяли путем квартования в одну усредненную пробу. В лабораторных условиях почвенные образцы высушивали до воздушно-сухого состояния, перетирали в фарфоровой ступке и просеивали через капроновое сито с размером ячеек 1 мм.

Пробоподготовка проведена с использованием мокрого озоления в концентрированной $\mathrm{HNO}_{3}$. Пробы анализировали на содержание $\mathrm{Cd}$ и $\mathrm{Ni}$ на атомно-абсорбционном спектрометре «ZEEnit-650» (Германия) [29]. В почвенных образцах определяли массовые концентрации валовых и подвижных форм металлов, извлекаемые ацетатно-аммонийным буфером с $\mathrm{pH}=4,8$. Всего проанализировано 648 проб хвои, 648 проб ветвей, 600 проб корней и 360 проб почвы. Кроме того, в почвенных образцах определяли величину $\mathrm{pH}$ солевой вытяжки $(\mathrm{KCl})$ потенциометрическим методом.

Статистическая обработка данных выполнена с помощью пакета программы Microsoft Office Excel. Данные представлены в виде средней арифметической \pm стандартное отклонение $(\mathrm{M} \pm \mathrm{SD})$. Оценка статистической значимости различий проведена согласно $t$-критерию Стьюдента. Различия считали статистически значимыми при $p<0,05$. 


\section{Результаты исследования и обсуждение}

Нарушение химического равновесия в окружающей среде, вызванное избыточным поступлением токсических веществ, со временем отражается на жизненном состоянии древостоев, приводя к их ослаблению и отмиранию. Однако на первых этапах могут проявляться признаки ускоренного старения лишь отдельных систем организма или отдельных экземпляров деревьев.

Таблица 3 [Table 3]

Относительное жизненное состояние насаждений лиственницы Сукачева (Larix sukaczewii Dyl.) в условиях промышленного центра и в зоне условного контроля

[Relative vital state of Larix Sukaczewii Dyl. in the industrial center and in the area of conditional control]

\begin{tabular}{|c|c|c|c|c|c|c|c|c|}
\hline \multirow[b]{2}{*}{$\begin{array}{l}\text { ППП } \\
{[\text { РТР }]}\end{array}$} & \multicolumn{6}{|c|}{$\begin{array}{c}\text { Количество деревьев по категориям на ППП, шт. } \\
\text { [Number of trees by category at the PTP, pcs.] }\end{array}$} & \multicolumn{2}{|c|}{$\begin{array}{l}\text { OЖС насаждения } \\
\text { [RVS of plantations] }\end{array}$} \\
\hline & $\begin{array}{l}\text { Всего } \\
{[\text { Total }]}\end{array}$ & $\begin{array}{c}\text { Здоро- } \\
\text { вые } \\
{[\text { Healthy }]}\end{array}$ & $\begin{array}{c}\text { Осла- } \\
\text { бленные } \\
\text { [Weakened] }\end{array}$ & $\begin{array}{c}\text { Сильно } \\
\text { осла- } \\
\text { бленные } \\
\text { [Strongly } \\
\text { weakened] }\end{array}$ & $\begin{array}{c}\text { Отмира- } \\
\text { ющие } \\
\text { [Dying] }\end{array}$ & $\begin{array}{l}\text { Сухие } \\
\text { [Dead] }\end{array}$ & $L_{N}, \%$ & $\begin{array}{l}\text { Категория } \\
\text { [Category] }\end{array}$ \\
\hline № 1 & 20 & 6 & 11 & 1 & 0 & 2 & 71,50 & $\begin{array}{c}\text { Осла- } \\
\text { бленное } \\
\text { [Weakened] }\end{array}$ \\
\hline № 2 & 20 & 15 & 4 & 0 & 0 & 1 & 86,20 & $\begin{array}{l}\text { Здоровое } \\
\text { [Healthy] }\end{array}$ \\
\hline
\end{tabular}

Примечание. ППП - постоянная пробная площадь; ОЖС - относительное жизненное состояние; $\mathrm{L}_{\mathrm{N}}$ - относительное жизненное состояние древостоя, рассчитанное по числу деревьев; № 1 - в условиях промышленного центра; № 2 - в зоне условного контроля. [Note. PTP - Permanent Trial Plot; RVS - Relative Vital State; $\mathrm{L}_{\mathrm{N}}$ - Relative vital state of the stand, calculated by the number of trees; 1 - In the industrial center; 2 - In the area of conditional control].

Изучение относительного жизненного состояния насаждений лиственницы Сукачева показало, что на ППП № 1 растения более ослаблены по сравнению с контрольным участком. Внешние признаки угнетения деревьев выражались в уменьшении густоты кроны на $20-25 \%$, увеличении количества мертвых ветвей до 25-30\%, поражении ассимиляционного аппарата хлорозами и некрозами (в среднем на 15\%). При этом распространение хлорозов и некрозов хвои у лиственницы Сукачева в условиях влияния промышленного центра происходило однотипно - от кончика к ее основанию. Вышеперечисленные факторы способствовали снижению устойчивости защитных лесных насаждений в промышленной зоне. Деревья, относящиеся к категории «ослабленные», составляли 55\% древостоя, сухостой достигал $10 \%$, к категории «здоровые» отнесены $30 \%$. Соответственно, относительное жизненное состояние всего насаждения на ППП № 1 характеризовалось как «ослабленное» $\left(\mathrm{L}_{\mathrm{N}}=71,50 \%\right)$ (табл. 3$)$. В то же время снижения класса бонитета не наблюдалось (см. табл. 1). 
На удаленном от промышленных предприятий контрольном участке деревья имели лучше сформированную крону (средняя густота $-82 \%$ ) и меньшее количество мертвых сучьев на стволе (в среднем 21\%). Повреждение хвои хлорозами не превышало $11 \%$. Общее число здоровых лиственниц на ППП № 2 составляло $75 \%$, ослабленных $-20 \%$, сухих $-5 \%$. Показатель $\mathrm{L}_{\mathrm{N}}$, равный $86,20 \%$, характеризовал древостой как «здоровый».

Результаты химического анализа почвенных образцов выявили различия между содержанием рассматриваемых металлов в зоне влияния Стерлитамакского промышленного центра и в зоне условного контроля (табл. 4). Так, на ППП № 1 концентрация валовой формы Сd статистически значимо $(p<0,01)$ выше, чем на ППП № 2, в 4 раза, а содержание валовой формы $\mathrm{Ni}$ статистически значимо выше в 5 раз $(p<0,05)$. Обобщение многолетних данных по содержанию подвижных (биологически доступных) форм анализируемых металлов показало, что на ППП № 1 средняя концентрация Сd составляет 0,58 мг/кг, что статистически значимо $(p<0,01)$ выше показателя контрольного участка в 6 раз. Среднее содержание Ni на ППП № 1, равное 9,40 мг/кг, статистически значимо $(p<0,05)$ выше показателя ППП № 2 в 3 раза.

Таблица 4 [Table 4]

Усредненные концентрации валовых и подвижных форм металлов в почвенном покрове под насаждениями лиственницы Сукачева (Larix sukaczewii Dyl.)

[Averaged concentrations of gross and mobile forms of metals in the soil cover under the stands of Larix sukaczewii Dyl.] $(M \pm S D)$

\begin{tabular}{|c|c|c|c|c|}
\hline \multirow{2}{*}{$\begin{array}{l}\text { ППП } \\
\text { [РТР] }\end{array}$} & \multicolumn{2}{|c|}{$\begin{array}{c}\text { Валовая форма, мг/кг } \\
\text { [Gross form, mg / kg] }\end{array}$} & \multicolumn{2}{|c|}{$\begin{array}{c}\text { Подвижная форма, мг/кг } \\
\text { [Mobile form, mg / kg] }\end{array}$} \\
\hline & $\mathrm{Cd}$ & $\mathrm{Ni}$ & $\mathrm{Cd}$ & $\mathrm{Ni}$ \\
\hline № 1 & $5,04 \pm 0,32$ & $108,07 \pm 7,40$ & $0,58 \pm 0,04$ & $9,40 \pm 0,59$ \\
\hline № 2 & $1,22 \pm 0,07 *$ & $23,50 \pm 2,14^{* *}$ & $0,10 \pm 0,01 *$ & $3,61 \pm 0,31 * *$ \\
\hline
\end{tabular}

Примечание. ППП - постоянная пробная площадь; № 1 - в условиях промышленного центра; № 2 - в зоне условного контроля; * $p<0,01 ; * * p<0,05$.

[Note. PTP - Permanent Trial Plot; № 1 - In the industrial center; № 2 - In the area of conditional control; $\left.{ }^{*} p<0.01 ; * * p<0.05\right]$.

Как известно, ТМ проникают в ткани древесных растений в основном через корневую систему при процессе поглощения, в меньшей степени выражено фолиарное поступление. Интенсивность процесса поглощения тяжелых металлов из почвенного покрова определяется целым рядом факторов - катионообменной способностью и гранулометрическим составом почвы, температурой, уровнем концентрации макро- и микроэлементов в среде, присутствием различных органических соединений и т.д. Однако главным фактором, контролирующим поглощение металлов, выступает $\mathrm{pH}$ почвы. Отмечается, что щелочная среда снижает подвижность ТМ, в то время как кислая, наоборот, повышает. Например, кадмий наиболее подвижен в кислых почвах в диапазоне 4,5-5,5 ед. pH [30]. Установлено, что значитель- 
ное количество элементов, в том числе и $\mathrm{Ni}$, иммобилизуется в почвенном покрове из-за ее защелачивания [16]. На территории г. Стерлитамак, где также наблюдается высокое содержание в выбросах оксида кальция, значение $\mathrm{pH}$ почвы под насаждениями лиственницы Сукачева варьировало в пределах 6,55-6,90 ед. В то же время показатели загрязненного и контрольного участков между собой статистически значимо не различались.

При изучении корненасыщенности почвенного покрова выявлено, что для зоны условного контроля характерно поверхностное распространение поглощающих корней (рис. 2). Согласно результатам количественного учета, основная их масса (55-60\%) располагалась в верхнем 30-сантиметровом слое почвы. При этом максимальная масса поглощающих корней лиственницы Сукачева обнаруживалась на глубине от 10 до $20 \mathrm{~cm}-78,51 \pm 4,10$ г/ ${ }^{2}$. На глубине от

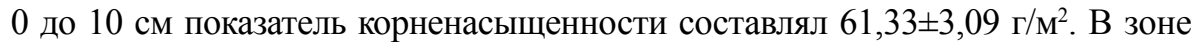
влияния Стерлитамакского промышленного центра наблюдалась несколько иная картина - поглощающих корней в слоях почвы 0-10 и 10-20 см содержалось в 2-3 раза меньше. Так, у здоровых деревьев в верхнем слое почвенного

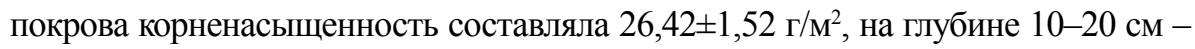

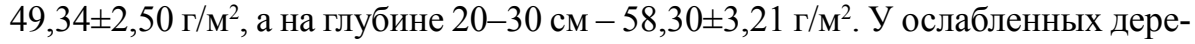
вьев на ППП № 1 наблюдалась такая же закономерность, однако показатели корненасыщенности оказались ниже, чем у здоровых лиственниц. Минимальными значениями насыщенности почвы поглощающими корнями характеризовались более глубокие слои (от 50 до 100 см) как в зоне условного контроля, так на загрязненном участке.

Характер распространения корней в почве в определенной степени зависит от почвенного профиля, в том числе уровня залегания грунтовых вод. Так как условия произрастания на изученных ППП идентичные и различие заключалось лишь в уровне техногенного загрязнения, можно предположить, что снижение насыщенности почвы поглощающими корнями в зоне влияния Стерлитамакского промышленного центра связано с повышением концентрации ТМ в грунте. Длительное воздействие поллютантов в высоких концентрациях привело к существенной перестройке всасывающего аппарата корневой системы лиственницы Сукачева. Как отмечают I.V. Seregin and A.D. Kozhevnikova [31], в связи с тем, что ТМ поступают в растения в основном через подземные органы, токсическое действие этих загрязнителей четко прослеживается по ингибированию роста и развития корневой системы. При проведении исследований с непродолжительным воздействием высоких концентраций кадмия на клональные проростки лиственницы подавления роста корня не наблюдалось [10].

Однако аналогичные опыты, но с более длительным временем воздействия кадмия привели к снижению массы как подземных, так и надземных органов лиственницы [11].

Распределение кадмия по фракциям корневой системы лиственницы Сукачева показано на рис. 3. Как видно, наиболее высокие концентрации ме- 
талла обнаруживались в полускелетных и поглощающих корнях у здоровых

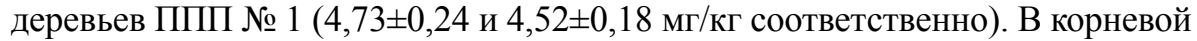
системе ослабленных деревьев с ППП № 1 данный элемент содержался в меньших количествах - от 2,33 $\pm 0,12$ до 3,21 $\pm 0,17$ мг/кг. При этом имели место статистически значимые различия $(\mathrm{p}<0,05)$. На ППП № 2 кадмий также больше аккумулировался в полускелетных корнях $(\mathrm{p}<0,05)$, однако его со-

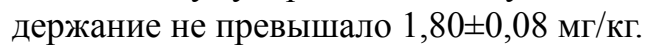

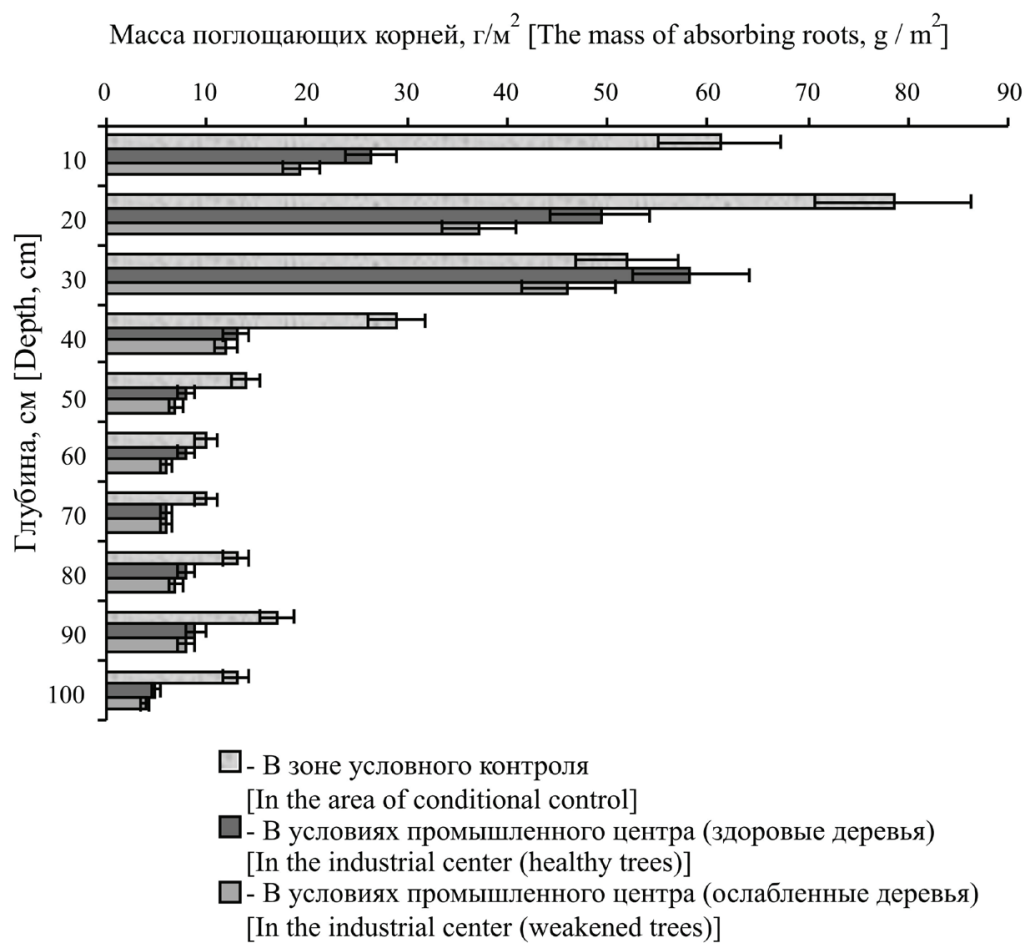

Pис. 2. Насыщенность почвы поглощающими корнями лиственницы Сукачева (Larix sukaczewii Dyl.) в условиях промышленного центра

и в зоне условного контроля $(M \pm S D)$

[Fig. 2. Soil saturation with absorbing roots of Larix sukaczewii Dyl. in the industrial center and in the area of conditional control. On the $\mathrm{X}$-axis -

The mass of absorbing roots, $\mathrm{g} / \mathrm{m}^{2}$; on the Y-axis - Depth, $\left.\mathrm{cm}(M \pm S D)\right]$

Распределение никеля по фракциям корневой системы лиственницы несколько отличалось (рис. 4). Максимальная концентрация металла определялась в поглощающих корнях как у здоровых, так и у ослабленных деревьев - 98,45 $\pm 14,60$ и $65,30,52 \pm 7,81$ мг/кг соответственно. При этом и в зоне условного контроля, и на загрязненной территории процесс перемещения никеля из поглощающих корней в проводящие корни выражен в менышей степени, чем у кадмия.

На рис. 5 и 6 представлены усредненные данные по содержанию металлов в хвое, ветвях и корневой системе лиственницы. 


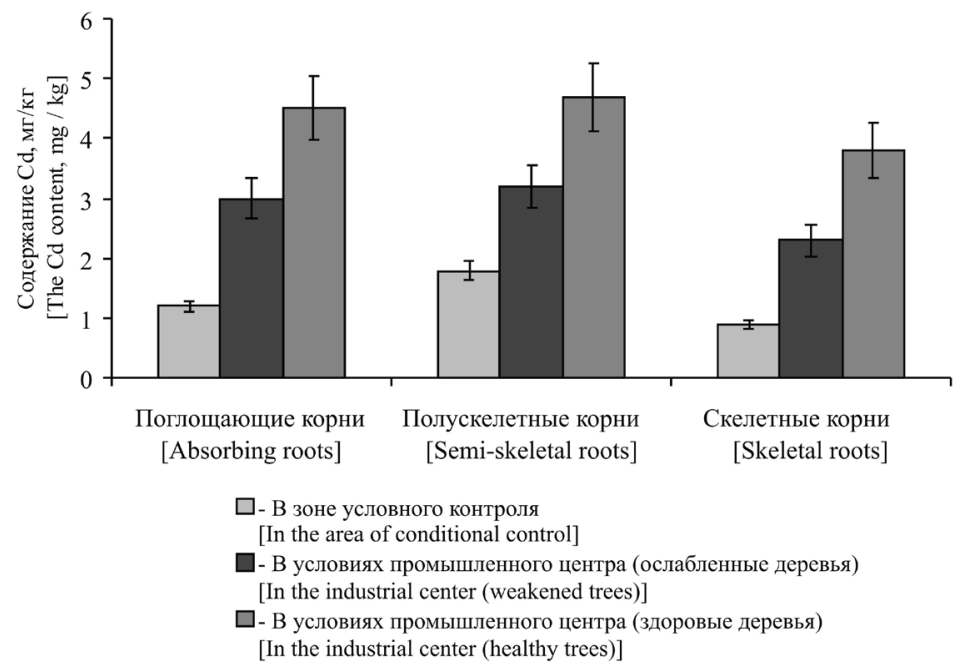

Рис. 3. Содержание $\mathrm{Cd}$ (мг/кг) в поглощающих, полускелетных и скелетных корнях лиственницы Сукачева (Larix sukaczewii Dyl.)

в условиях промышленного центра и в зоне условного контроля $(M \pm S D)$

[Fig. 3. The content of $\mathrm{Cd}(\mathrm{mg} / \mathrm{kg})$ in the absorbing, semi-skeletal and skeletal roots

of Larix sukaczewii Dyl. in the industrial center and in the area of conditional control.

On the X-axis - Types of Larix sukaczewii roots; on the Y-axis - The Cd content, $\mathrm{mg} / \mathrm{kg}(M \pm S D)]$

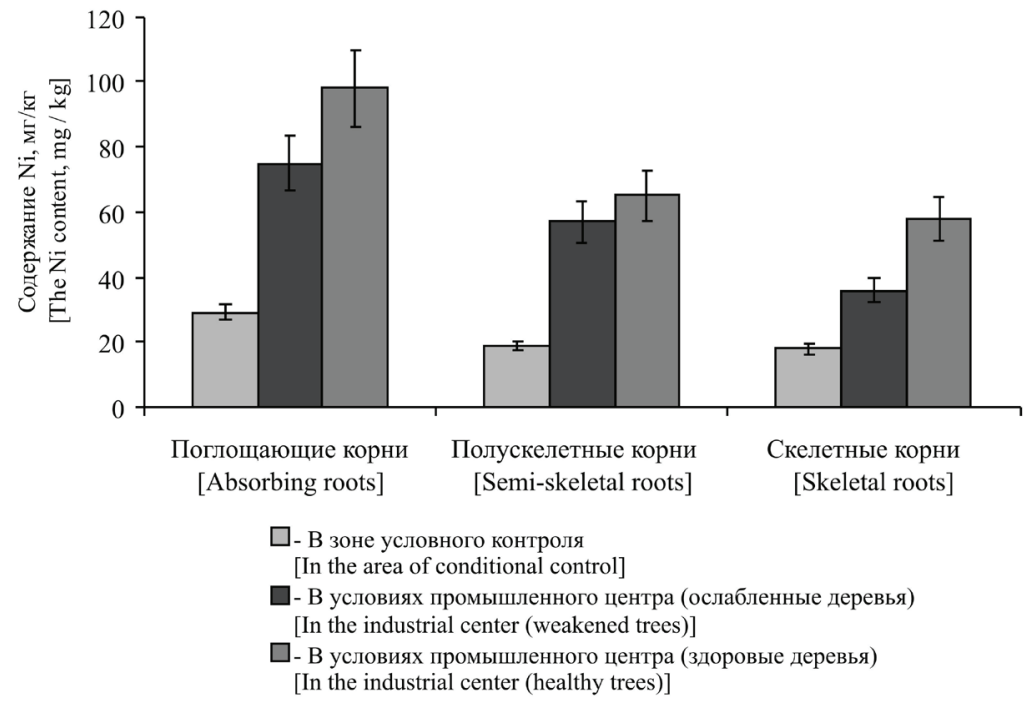

Рис. 4. Содержание $\mathrm{Ni}$ (мг/кг) в поглощающих, полускелетных и скелетных корнях лиственницы Сукачева (Larix sukaczewii Dyl.) в условиях промышленного центра и в зоне условного контроля $(M \pm S D)$

[Fig. 4. The content of $\mathrm{Ni}(\mathrm{mg} / \mathrm{kg})$ in the absorbing, semi-skeletal and skeletal roots of Larix sukaczewii Dyl. in the industrial center and in the area of conditional control. On the X-axis - Types of Larix sukaczewii roots; on the Y-axis - The Ni content, $\mathrm{mg} / \mathrm{kg}(M \pm S D)]$ 


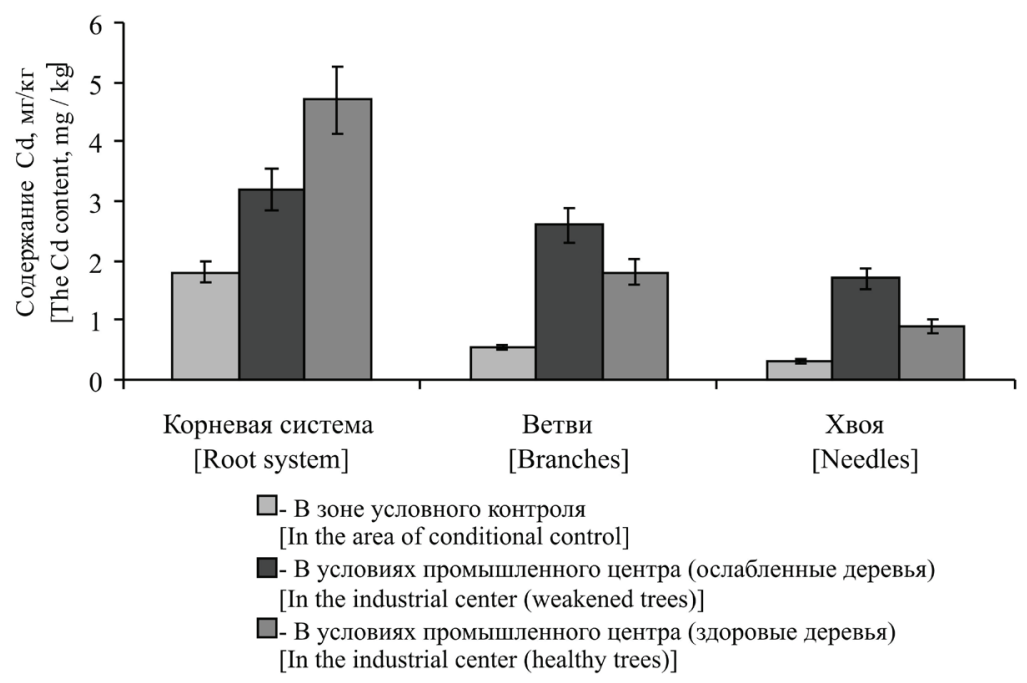

Рис. 5. Содержание $\mathrm{Cd}$ (мг/кг) в надземных и подземных органах лиственницы Сукачева (Larix sukaczewii Dyl.) в условиях промышленного центра и в зоне условного контроля $(M \pm S D)$

[Fig. 5. The content of $\mathrm{Cd}(\mathrm{mg} / \mathrm{kg})$ in the aboveground and underground organs of Larix sukaczewii Dyl. in the industrial center and in the area of conditional control.

On the X-axis - Aboveground and underground organs of Larix sukaczewii; on the Y-axis - The Cd content, $\mathrm{mg} / \mathrm{kg}(M \pm S D)]$

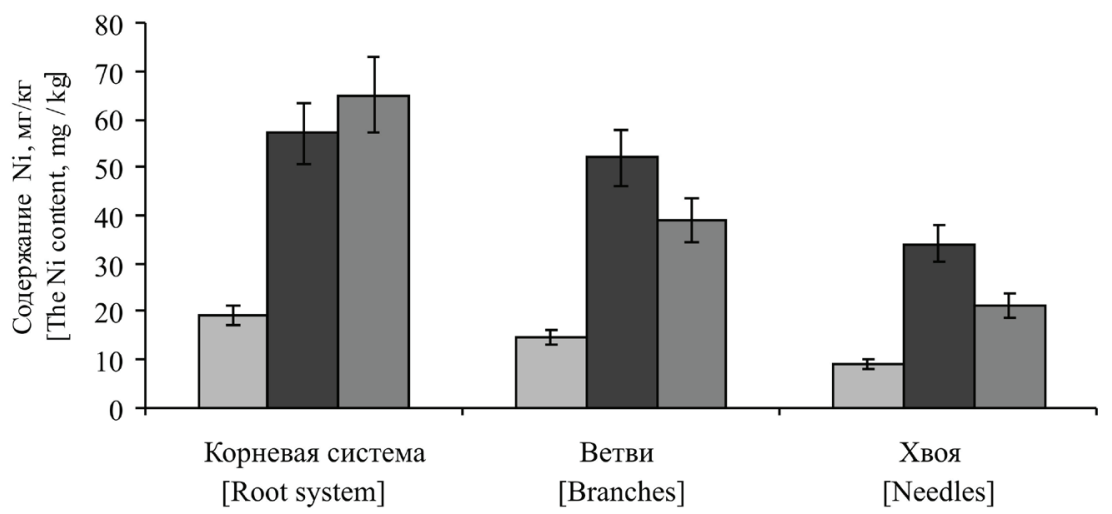

$\square$ - В зоне условного контроля

[In the area of conditional control]

$\square$ - В условиях промышленного центра (ослабленные деревья) [In the industrial center (weakened trees)]

$\square$ - В условиях промышленного центра (здоровые деревья) [In the industrial center (healthy trees)]

Рис. 6. Содержание $\mathrm{Ni}$ (мг/кг) в надземных и подземных органах лиственницы Сукачева (Larix sukaczewii Dyl.) в условиях промышленного центра и в зоне условного контроля $(M \pm S D)$

[Fig. 6. The content of $\mathrm{Ni}(\mathrm{mg} / \mathrm{kg})$ in the aboveground and underground organs of Larix sukaczewii Dyl. in the industrial center and in the area of conditional control. On the X-axis Aboveground and underground organs of Larix sukaczewii; on the Y-axis - The Ni content, $\mathrm{mg} / \mathrm{kg}(M \pm S D)]$ 
Хвоя характеризовалась наименьшими концентрациями кадмия и никеля. Вместе с тем в тканях лиственницы Сукачева никель аккумулировался в больших количествах, чем кадмий. При сравнении данных по двум пробным площадям можно видеть, что в условиях Стерлитамакского промышленного центра концентрация ТМ в надземных и подземных органах достоверно выше, чем на контрольном участке $(\mathrm{p}<0,05)$.

Согласно A. Kabata-Pendias [32], фоновое содержание кадмия в надземной части растений составляет $0,05-0,60$ мг/кг сухого вещества, токсичное - 1,0-70,0 мг/кг. Нормальное содержание никеля в надземных органах большинства видов растений определяется на уровне $0,1-5,0$ мг/кг сухого вещества, а концентрация выше 10,0 мг/кг считается токсичной. На изученной нами территории в надземных органах лиственницы Сукачева средняя концентрация кадмия в зоне условного контроля варьировала от 0,30 до 0,55 мг/кг, в условиях Стерлитамакского промышленного центра - в диапазоне, токсичном для растений (1,5-3,0 мг/кг). Концентрация никеля в надземных органах лиственницы чаще определялась как токсичная: в зоне условного контроля варьировала от 9,0 до 15,0 мг/кг, в условиях Стерлитамакского промышленного центра - от 21 до 52,0 мг/кг.

Кадмий принадлежит к наиболее токсичным для растений элементам. Установлено, что его высокие концентрации приводят к изменениям в проницаемости клеточных мембран и активности ряда ферментов, снижают интенсивность фотосинтеза, вызывая тем самым окислительный стресс [31, $33,34]$. В отличие от кадмия, никель считается необходимым для растений элементом, однако при повышенных концентрациях также оказывает ингибирующее действие на физиологические процессы. Интоксикация может проявляться в замедлении процессов роста и фотосинтеза, нарушении водного и минерального обмена, внешне проявляющимися как межжилковый хлороз и некроз листьев [31, 35-37]. Как отмечено выше, внешние признаки токсического действия ТМ у лиственничных насаждений на ППП № 1 выявлялись чаще, чем на ППП № 2.

В зависимости от интенсивности накопления и распределения металлов по органам растений выделяют две контрастные группы - исключатели и аккумуляторы. К исключателям относят растения, накапливающие металлы преимущественно в подземных органах. Аккумуляторы накапливают металлы главным образом в надземной части, а при определенных условиях проявляют себя как гипераккумуляторы. К гипераккумуляторам никеля относят растения, способные концентрировать металл в листьях на уровне более 1000 мг/кг сухой массы, к гипераккумуляторам кадмия - при концентрировании металла в листьях свыше 100 мг/кг сухой массы [38]. Как видно из результатов количественного химического анализа по распределению изученных металлов в надземных и подземных частях, лиственница Сукачева является исключателем. При этом переход из корней в надземные побеги у кадмия выражен в меньшей степени по сравнению в никелем. I.V. Seregin 
and A.D. Kozhevnikova [31] отмечают, что низкое содержание металлов в надземных органах растений-исключателей определяется барьерной функцией корневой системы. В то же время ткани, выполняющие барьерную функцию (эндодерма и экзодерма), преимущественно ограничивают транспорт только «апопластических» ионов $(\mathrm{Cd})$, в то время как транспорт «симпластических» ионов (Ni) - незначительно.

Следует отметить, что в распределении элементов по органам у здоровых и ослабленных деревьев также обнаруживаются различия. У здоровых лиственниц в надземной части сосредоточивается от 35 до 40\% кадмия, а в корнях - 60-65\%. У ослабленных деревьев по сравнению со здоровыми, отмечаются более высокие концентрации элемента в надземных органах. То есть в их корневой системе кадмий иммобилизуется в меньшей степени. Такая же закономерность наблюдается и при аккумуляции никеля. В данном случае можно говорить о снижении барьерной функции корневой системы у ослабленных деревьев.

\section{Заключение}

Проведенные исследования позволили выявить, что в непосредственной близости от промышленной зоны г. Стерлитамак деревья лиственницы Сукачева более ослаблены по сравнению с условным контролем. Внешние признаки угнетения проявляются в уменьшении густоты кроны, увеличении количества мертвых ветвей, поражении ассимиляционного аппарата хлорозами и некрозами. Повышение концентрации тяжелых металлов в корнеобитаемом слое почвы приводит к снижению доли поглощающих корней. На загрязненном участке содержание кадмия в хвое и ветвях выше в 5-6 раз, никеля - в 3-4 раза. В подземных органах содержание элементов по сравнению с условным контролем повышено в 2,5-4 раза. У ослабленных деревьев концентрация металлов в надземной части выше, чем у здоровых лиственниц, что может свидетельствовать о снижении барьерной функции корневой системы. Несмотря на то, что относительное жизненное состояние древостоя на загрязненном участке характеризуется как «ослабленное», снижения класса бонитета не наблюдается. Проведение оперативных лесохозяйственных мероприятий в санитарно-защитных насаждениях лиственницы не требуется. Рекомендуются своевременные санитарные рубки и дальнейший мониторинг.

\section{Лumepamypa}

1. Ali H., Khan E., Sajad M.A. Phytoremediation of heavy metals - Concepts and applications // Chemosphere. 2013. Vol. 91, № 7. PP. 869-881. doi: 10.1016/j.chemosphere.2013.01.075

2. Kakkar P., Jaffery F.N. Biological markers for metal toxicity // Environmental Toxicology and Pharmacology. 2005. Vol. 19, № 2. PP. 335-349. doi: 10.1016/j.etap.2004.09.003

3. Heavy Metals in Soils: Trace Metals and Metalloids in Soils and their Bioavailability. Alloway B.J., ed. Dordrecht, Netherlands ; New York : Springer, 2013. 632 p. 
4. Неверова О.А., Колмогорова Е.Ю. Ксерофитизация листьев древесных растений как показатель загрязнения атмосферного воздуха (на примере г. Кемерово) // Известия высших учебных заведений. Лесной журнал. 2002. № 3. С. 29-33.

5. Кулагин А.А., Шагиева Ю.А. Древесные растения и биологическая консервация промышленных загрязнителей. М. : Наука, 2005. 190 с.

6. Кирдянов А.В., Мыглан В.С., Пименов А.В., Кнорре А.А., Экарт А.К., Ваганов Е.А. Динамика усыхания лиственницы сибирской в зоне влияния техногенных эмиссий предприятий Норильского промышленного района // Сибирский экологический журнал. 2014. Т. 21, № 6. С. 945-952.

7. Giniyatullin R., Baktybaeva Z., Gabidullina G., Teltsova L. State and Environment Purifying Functions of Forest Stands Under Conditions of Polymetallic Pollution in the Industrial Center of Sterlitamak // Ecological-Socio-Economic Systems: Models of Competition and Cooperation (ESES 2019). Advances in Social Science, Education and Humanities Research / Shelomentsev A, Vasilieva O, Chepelyuk N and Orlov S, editors. 2020. Vol. 392. PP. 130-133. doi: 10.2991/assehr.k.200113.027

8. Касимов Н.С., Кошелева Н.Е., Сорокина О.И., Гунин П.Д., Бажа С.Н., Энх-Амгалан С. Эколого-геохимическая оценка состояния древесной растительности в г. Улан-Батор (Монголия) // Аридные экосистемы. 2011. Т. 17, № 4 (49). С. 14-31.

9. Гиниятуллин Р.Х., Кулагин А.Ю. Особенности содержания свинца в органах у здоровых и ослабленных деревьев березы повислой (Betula pendula Roth) в условиях промышленного загрязнения // Известия Уфимского научного центра РАН. 2018. № 3. С. 39-44.

10. Moudouma C.F.M., Riou C., Gloaguen V., Saladin G. Hybrid larch (Larix x eurolepis Henry): a good candidate for cadmium phytoremediation? // Environmental Science and Pollution Research. 2013. Vol. 20, № 3. PP. 1889-1894. doi: 10.1007/s11356-012-1419-6

11. Bonet A., Lelu-Walter M., Faugeron C., Gloaguen V., Saladin G. Physiological responses of the hybrid larch (Larix $\times$ eurolepis Henry) to cadmium exposure and distribution of cadmium in plantlets // Environmental Science and Pollution Research. 2016. Vol. 23, № 9. PP. 8617-8626. doi: 10.1007/s11356-016-6094-6

12. Juranović Cindrić I., Zeiner M., Starčević A., Stingeder G. Metals in pine needles: characterisation of bio-indicators depending on species // International Journal of Environmental Science and Technology. 2019. Vol. 16. PP. 4339-4346. doi: 10.1007/ s13762-018-2096-x

13. Коротеева Е.В., Веселкин Д.В., Куянцева Н.Б., Мумбер А.Г., Чащина О.Е. Накопление тяжелых металлов в разных органах березы повислой возле Карабашского медеплавильного комбината // Агрохимия. 2015. № 3. С. 88-96.

14. Kandziora-Ciupa M., Ciepał R., Nadgórska-Socha A., Barczyk G. Accumulation of heavy metals and antioxidant responses in Pinus sylvestris L. needles in polluted and non-polluted sites // Ecotoxicology. 2016. Vol. 25, № 5. PP. 970-981. doi: 10.1007/s10646-016-1654

15. Vorobeichik E.L., Pishchulin P.G. Industrial pollution reduces the effect of trees on forming the patterns of heavy metal concentration fields in forest litter // Russian Journal of Ecology. 2016. Vol. 47, № 5. PP. 431-441. doi: 10.1134/S1067413616050155

16. Ivanov Y.V., Kartashov A.V., Ivanova A.I., Ivanov V.P., Marchenko S.I., Nartov D.I., Kuznetsov V.V. Long-term impact of cement plant emissions on the elemental composition of both soils and pine stands and on the formation of Scots pine seeds // Environmental Pollution. 2018. Vol. 243. Pt. B. PP. 1383-1393. doi: 10.1016/j.envpol.2018.09.099

17. Путенихин В.П., Фарукшина Г.Г., Шигапов 3.Х. Лиственница Сукачева на Урале: изменчивость и популяционно-генетическая структура. М. : Наука, 2004. 275 с.

18. Николаева М.А., Орлова Л.В., Крестьянов А.А., Каматов Д.Е. Географическая изменчивость лиственницы в опытных лесных культурах Республики Башкортостан // Сибирский лесной журнал. 2019. №. 1. С. 30-43. doi: 10.15372/SJFS20190103

19. Атлас Республики Башкортостан / под ред. И.М. Япарова. Уфа : Китап, 2005. 420 с. 
20. Реестр особо охраняемых природных территорий Республики Башкортостан / под ред. Б.М. Миркина. Уфа : Гилем, 2006. 414 с.

21. О состоянии природных ресурсов и окружающей среды Республики Башкортостан в 2018 году: Государственный доклад. Уфа : Министерство природопользования и экологии Республики Башкортостан, 2019. 276 с.

22. Бактыбаева 3.Б., Сулейманов Р.А., Валеев Т.К., Рахматуллин Н.Р. Оценка воздействия нефтеперерабатывающей и нефтехимической промышленности на экологогигиеническое состояние объектов окружающей среды и здоровье населения (Обзор литературы) // Медицина труда и экология человека. 2018. № 4. С. 12-26.

23. Курамшин Э.М., Курамшина Н.Г., Нуртдинова Э.Э., Имашев У.Б. Геохимическая оценка загрязнения тяжелыми металлами городских почв Башкортостана // Башкирский химический журнал. 2015. Т. 22, № 2. С. 74-79.

24. Андреева Е.Н., Баккал И.Ю., Горшков В.В., Лянгузова И.В., Мазная Е.А., Нешатаев В.Ю., Ставрова Н.И., Ярмишко В.Т., Ярмишко М.А. Методы изучения лесных сообществ. СПб. : НИИХимии СпбГУ, 2002. 240 с.

25. Forest Ecology and Conservation: A handbook of techniques. Newton A., editor. Oxford : University Press, 2007. 454 p.

26. Лесные экосистемы и атмосферное загрязнение / под ред. В.А. Алексеева. Л. : Наука, 1990. $200 \mathrm{c}$.

27. Root Methods: A Handbook. Smit A.L., Bengough A.G., Engels C., Noordwijk M. van, Pellerin S., Geijn S.C. van de, editors. Berlin : Springer, 2000. 587 p.

28. Bargagli R. Trace Elements in Terrestrial Plants: An Ecophysiological Approach to Biomonitoring and Biorecovery. Berlin : Springer, 1998. 324 p.

29. Hill S.J., Fisher A.S. Atomic Absorption, Methods and Instrumentation. Encyclopedia of Spectroscopy and Spectrometry. 3rd ed. Lindon J.C, editor-in-chief. UK, London : Elsevier Publ.; 2017. pp. 37-43. doi: 10.1016/B978-0-12-803224-4.00099-6

30. Rademacher P. Atmospheric heavy metals and forest ecosystems: Work report of the Institute for World Forestry. Hamburg : Federal Research Centre for Forestry and Forest Products (BFH), Institute for World Forestry, 2003/12.

31. Seregin I.V., Kozhevnikova A.D. Roles of root and shoot tissues in transport and accumulation of cadmium, lead, nickel, and strontium // Russian Journal of Plant Physiology. 2008. Vol. 55, № 1. PP. 1-22. doi: 10.1007/s11183-008-1001-8

32. Kabata-Pendias A. Trace Elements in Soils and Plants. 4th ed. Boca Raton, FL, USA : CRC Press/Taylor \& Francis Group, 2010. 548 p.

33. Seregin I.V., Ivanov V.B. Physiological Aspects of Cadmium and Lead Toxic Effects on Higher Plants // Russian Journal of Plant Physiology. 2001. Vol. 48, № 4. PP. 523-544. doi: 10.1023/A:1016719901147

34. Andresen E., Kupper H. Cadmium toxicity in plants // Cadmium: From Toxicity to Essentiality. Metal Ions in Life Sciences. Sigel A., Sigel H., Sigel R.C.O., ed. Netherlands : Springer, 2013. Vol. 11. PP. 395-413.

35. Yusuf M., Fariduddin Q., Hayat S., Ahmad A. Nickel: An Overview of Uptake, Essentiality and Toxicity in Plants // Bulletin of Environmental Contamination and Toxicology. 2011. Vol. 86, № 1. PP. 1-17. doi: 10.1007/s00128-010-0171-1

36. Sreekanth T.V.M., Nagajyothi P.C., Lee K.D., Prasad T.N.V.K.V. Occurrence, physiological responses and toxicity of nickel in plants // International Journal of Environmental Science and Technology. 2013. Vol. 10, № 5. PP. 1129-1140. doi: 10.1007/s13762-013-0245-9

37. Parlak K.U. Effect of nickel on growth and biochemical characteristics of wheat (Triticum aestivum L.) seedlings // NJAS - Wageningen Journal of Life Sciences. 2016. Vol. 76. PP. 1-5. doi: 10.1016/j.njas.2012.07.001

38. Reeves R.D., Baker A.J.M., Jaffré T., Erskine P.D., Echevarria G., van der Ent A. A global database for plants that hyperaccumulate metal and metalloid trace elements // New Phytologist. 2018. Vol. 218, № 2. PP. 407-411. doi: 10.1111/nph.14907 
Поступила в редакцию 28.05.2020 2.; повторно 09.07.2020 2.;17.08.2020 2. принята 03.09.2020 г.; опубликована 25.09.2020 г.

\begin{abstract}
Авторский коллектив:
Гиниятуллин Рафак Хизбуллинович - д-р с.-х. наук, с.н.с. лаборатории лесоведения Уфимского Института биологии - обособленного структурного подразделения Уфимского федерального исследовательского центра РАН (Россия, 450054, г. Уфа, Россия, пр. Октября, 69).

ORCID iD: http://orcid.org/0000-0001-5729-3754

E-mail: grafak2012@yandex.ru

Бактыбаева Зульфия Булатовна - канд. биол. наук, с.н.с. отдела медицинской экологии Уфимского научно-исследовательского института медицины труда и экологии человека (Россия, 450106, г. Уфа, Россия, ул. С. Кувыкина, 94)

ORCID iD: http://orcid.org/0000-0003-1249-7328

E-mail: baktybaeva@mail.ru
\end{abstract}

Для цитирования: Гиниятуллин Р.Х., Бактыбаева З.Б. Особенности накопления Cd и Ni лиственницей Сукачева (Larix sukaczewii Dyl.) в условиях техногенеза // Вестн. Том. гос. ун-та. Биология. 2020. № 51. C. 141-161. doi: 10.17223/19988591/51/8

For citation: Giniyatullin RKh, Baktybaeva ZB. Features of Cd and Ni accumulation by Larix sukaczewii Dyl. under technogenesis. Vestnik Tomskogo gosudarstvennogo universiteta. Biologiya = Tomsk State University Journal of Biology. 2020;51:141-161. doi: 10.17223/19988591/51/8 In Russian, English Summary

\title{
Rafak Kh. Giniyatullin', Zulfiya B. Baktybaeva ${ }^{2}$
}

${ }^{1}$ Ufa Institute of Biology, Ufa Federal Research Centre of the Russian Academy of Sciences, Ufa, Russian Federation

${ }^{2}$ Ufa Research Institute of Occupational Health and Human Ecology, Ufa, Russian Federation

\section{Features of $\mathrm{Cd}$ and Ni accumulation by Larix sukaczewii Dyl. under technogenesis}

In industrially developed cities, sanitary-protective afforestation promotes the deposition of aeropollutants, as well as the absorption of toxicants from the soil. However, performing a function of a phytofilter for a long time negatively affects the vitality of the trees themselves. Among numerous pollutants of technogenic origin, the most toxic for living organisms, including plants, are heavy metals. Studying the absorption capacity of different species of woody plants and their reaction to increased concentrations of toxicants allows us to predict the stability of protective forest stands and design forestry measures. One of the species, widely used in creating sanitary protection zones in the Republic of Bashkortostan, is Larix sukaczewii Dyl., characterized by its resistance to extreme environmental factors. The adaptive abilities of this species to an increased content of heavy metals remain poorly studied. The aim of this study is to identify the features of the accumulation and distribution of heavy metals (Cd and Ni) by Larix sukaczewii and assess the relative living condition of the stand in Sterlitamak industrial center.

We conducted studies in 2007-2018 in the city of Sterlitamak ( $\left.53^{\circ} 38^{\prime} 00^{\prime \prime} \mathrm{N}, 55^{\circ} 57^{\prime} 00^{\prime \prime} \mathrm{E}\right)$, a major center of the chemical and oil refining industry of the Russian Federation. The establishment and description of trial plots was carried out according to generally accepted methods [Andreeva EN et al., 2002; Forest ecology..., 2007]. Permanent trial plot No. 1 measuring $20 \times 50 \mathrm{~m}$ was located $1-2 \mathrm{~km}$ from sources of petrochemical and chemical pollution (See Fig. 1). Permanent trial plot No. 2 measuring $18 \times 50 \mathrm{~m}$ was located in the area of conditional control (25-30 km from pollution sources). Trial areas were laid in coeval (about 55 years) and clean tree stands (See Table 1). The category of the vital state of an individual tree was determined by the auxiliary table (See Table 2). After summing up the number of trees by categories, we assessed the relative living 
conditions of the entire stand [Alekseev VA, 1990]. At a rate of $100 \%$ to $80 \%$, the stand was assessed as "healthy", at $79-50 \%$ as "weakened", at $49-20 \%$ as "strongly weakened", and at $19 \%$ and below as "completely destroyed". The study of the soil saturation with absorbing roots was carried out by the method of soil sections $1 \times 1 \times 1 \mathrm{~m}$ in size [Root Methods, 2000]. The roots were sorted by fractions: less than $1 \mathrm{~mm}$ in diameter (absorbing roots), 1-3 $\mathrm{mm}$ (half-skeletal roots), and more than $3 \mathrm{~mm}$ (skeletal roots). We determined the weight of the roots in the air-dry state. To study the metal content, annually during the growing season, we performed repeated re-selection of needles, branches and roots. At the same time, we took soil samples from the depth of $0-20 \mathrm{~cm}$. The samples were dried to an air-dry state and analyzed on a "ZEEnit-650" atomic absorption spectrometer (Germany) [Hill SJ, Fisher AS, 2017]. In soil samples, we determined gross and mobile forms of metals. Data are presented as arithmetic mean \pm standard deviation $(M \pm S D)$. Differences were considered statistically significant at $p<0.05$.

We found that at the permanent trial plot No. 1, the trees are more weakened in comparison to the conditional control. External signs of oppression were expressed in a crown density decrease to $75-80 \%$, an increase in the number of dead branches to $25-30 \%$, and damage to the assimilation apparatus by chlorosis and necrosis (on average by 15\%). Trees classified as "weakened" accounted for $55 \%$ of the stand, and deadwood reached $10 \%$. The relative vital condition of the entire stand was characterized as "weakened" (See Table 3). In the area of conditional control, the forest stand corresponded to the "healthy" category. Moreover, the trees had a better formed crown (average density is $82 \%)$ and fewer dead branches on the trunk $(21 \%$ on average). Needles damage by chlorosis was not more than $11 \%$. The results of chemical analysis of soil samples revealed statistically significant differences $(p<0.05)$ between the content of the metals in the zone of influence of the industrial center of Sterlitamak and in the area of conditional control (See Table 4). Higher concentrations of cadmium and nickel were found at the permanent trial plot No. 1. The leached chernozem prevailed in the soil cover. The $\mathrm{pH}$ of the soil according to many years of research ranged from 6.55-6.90 units. The bulk of the absorbing larch roots was located at a depth of 0-30 cm (See Fig. 2). Moreover, in the control area, the root saturation of the soil reached $78.51 \pm 4.10 \mathrm{~g} / \mathrm{m}^{2}$. In the influence zone of Sterlitamak industrial center, we observed a decrease in the proportion of absorbing roots: in healthy trees 2 times and in weakened trees 2-3 times. Perhaps, this is due to higher concentrations of metals in the surface of soil layer at a permanent trial plot No. 1, which led to a significant restructuring of the larch suction root apparatus. Chemical analysis of plant samples showed that in the contaminated area the content of cadmium in needles and branches is statistically significantly $(p<0.05)$ higher by $5-6$ times and that of nickel by 3-4 times. In underground organs, the content of elements in comparison to the conditional control increased 2.5-4 times $(p<0.05)$. Besides, in the underground part, nickel is mainly accumulated in absorbing roots, and cadmium in absorbing and semi-skeletal ones (See Fig. 3 and 4). The movement of nickel from absorbing roots to conductive roots is less expressed than cadmium. In the aerial part of trees, the metal content in the branches is higher than in the needles (See Fig. 5 and 6). At the same time, in healthy trees, the barrier function of the root system is preserved, which prevents the excess intake of pollutants in the aboveground organs. Despite the fact that the relative vital condition of the stand at the contaminated site is characterized as "weakened", there is no decrease in the quality class. It is not required to carry out operational forestry activities in the sanitary-protective larch plantations. Timely sanitary felling and further monitoring are recommended.

The paper contains 6 Figures, 4 Tables and 38 References.

Key words: heavy metals; sanitary-protective afforestation; relative living state of the stand; root saturation of the soil; Sterlitamak industrial center; Cis-Urals. 
Funding: This work was performed as a part of the state task of the Ministry of Education and Science of Russia (Project No 075-00326-19-00 on the topic AAAA-A18-118022190102-3). A part of the results was obtained using the equipment of the Regional Center for Collective Use "Agidel".

The Authors declare no conflict of interest.

\section{References}

1. Ali H, Khan E, Sajad MA. Phytoremediation of heavy metals - Concepts and applications. Chemosphere. 2013;91(7):869-881. doi: 10.1016/j.chemosphere.2013.01.075

2. Kakkar P, Jaffery FN. Biological markers for metal toxicity. Environmental Toxicology and Pharmacology. 2005;19(2):335-349. doi: 10.1016/j.etap.2004.09.003

3. Heavy Metals in Soils: Trace Metals and Metalloids in Soils and their Bioavailability. Alloway BJ, editor. Dordrecht, Netherlands; New York: Springer Publ.; 2013. 632 p.

4. Neverova OA, Kolmogorova EYu. Kserofitizatsiya list'ev drevesnykh rasteniy kak pokazatel' zagryazneniya atmosfernogo vozdukha (na primere g. Kemerovo) [Xerophytization of wood plant leaves as index of atmospheric air pollution (on the example of Kemerovo)]. Lesnoy Zhurnal = Russian Forestry Journal. 2002;3:29-33. In Russian

5. Kulagin AA, Shagieva YuA. Drevesnye rasteniya i biologicheskaya konservatsiya promyshlennykh zagryazniteley [Woody plants and biological conservation of industrial pollutants]. Moscow: Nauka Publ.; 2005. 190 p. In Russian

6. Kirdyanov AV, Pimenov AV, Knorre AA, Ekart AK, Vaganov EA, Myglan VS. Dieoff dynamics of Siberian larch under the impact of pollutants emitted by Norilsk enterprises. Contemporary Problems of Ecology. 2014;7(6):679-684. doi: 10.1134/ S1995425514060055

7. Giniyatullin R, Baktybaeva Z, Gabidullina G, Teltsova L. State and Environment Purifying Functions of Forest Stands Under Conditions of Polymetallic Pollution in the Industrial Center of Sterlitamak. Ecological-Socio-Economic Systems: Models of Competition and Cooperation (ESES 2019). Advances in Social Science, Education and Humanities Research. Shelomentsev A, Vasilieva O, Chepelyuk N and Orlov S, editors. 2020;392:130133. doi: 10.2991/assehr.k.200113.027

8. Kasimov NS, Kosheleva NE, Sorokina OI, Gunin PD, Bazha SN, Enkh-Amgalan S. An ecological-geochemical assessment of the state of woody vegetation in Ulaanbaatar city (Mongolia). Arid Ecosystems. 2011;1(4):201-213. doi: 10.1134/S2079096111040081

9. Giniyatullin RKh, Kulagin AYu. Osobennosti soderzhaniya svintsa v organakh u zdorovykh i oslablennykh derev"ev berezy povisloy (Betula pendula Roth) v usloviyakh promyshlennogo zagryazneniya [Features of lead content in healthy and weakened drooping birch trees (Betula pendula Roth) under industrial pollution conditions]. Izvestia Ufimskogo Nauchnogo Tsentra RAN = Proceedings of the RAS Ufa Scientific Centre. 2018;3:39-44. In Russian

10. Moudouma CFM, Riou C, Gloaguen V, Saladin G. Hybrid larch (Larix x eurolepis Henry): a good candidate for cadmium phytoremediation? Environmental Science and Pollution Research. 2013;20(3):1889-1894. doi: 10.1007/s11356-012-1419-6

11. Bonet A, Lelu-Walter M, Faugeron C, Gloaguen V, Saladin G. Physiological responses of the hybrid larch (Larix $\times$ eurolepis Henry) to cadmium exposure and distribution of cadmium in plantlets. Environmental Science and Pollution Research. 2016;23(9):86178626. doi: 10.1007/s11356-016-6094-6

12. Juranović Cindrić I, Zeiner M, Starčević A, Stingeder G. Metals in pine needles: characterisation of bio-indicators depending on species. Int $J$ of Environmental Science and Technology. 2019;16:4339-4346. doi: 10.1007/s13762-018-2096-х

13. Koroteeva EV, Veselkin DV, Kuyantseva NB, Mumber AG, Chashchina OE. Nakoplenie tyazhelykh metallov $\mathrm{v}$ raznykh organakh berezy povisloy vozle karabashskogo medeplavil"nogo kombinata [Accumulation of heavy metals in the different Betula 
pendula Roth organs near the karabash copper smelter]. Agrokhimiya $=$ Agrochemistry. 2015;3:88-96. In Russian

14. Kandziora-Ciupa M, Ciepał R, Nadgórska-Socha A, Barczyk G. Accumulation of heavy metals and antioxidant responses in Pinus sylvestris L. needles in polluted and non-polluted sites. Ecotoxicology. 2016;25(5):970-981. doi: 10.1007/s10646-016-1654

15. Vorobeichik EL, Pishchulin PG. Industrial pollution reduces the effect of trees on forming the patterns of heavy metal concentration fields in forest litter. Russian $J$ Ecology. 2016;47(5):431-441. doi: 10.1134/S1067413616050155

16. Ivanov YV, Kartashov AV, Ivanova AI, Ivanov VP, Marchenko SI, Nartov DI, Kuznetsov VV. Long-term impact of cement plant emissions on the elemental composition of both soils and pine stands and on the formation of scots pine seeds. Environmental Pollution. 2018;243(Pt B):1383-1393. doi: 10.1016/j.envpol.2018.09.099

17. Putenikhin VP, Farukshina GG, Shigapov ZKh. Listvennitsa Sukacheva na Urale: izmenchivost' i populyatsionno-geneticheskaya struktura [Larix sukaczewii in the Urals: Variability and population-genetic structure]. Moscow: Nauka Publ.; 2004. 275 p. In Russian

18. Nikolaeva MA, Orlova LV, Krest'yanov AA, Kamatov DN. Geographical variability of larch in the experimental forest crops of the Republic of Bashkortostan. Sibirskij Lesnoj Zurnal $=$ Siberian Journal of Forest Science. 2019;1:30-43. doi: 10.15372/SJFS20190103 In Russian

19. Atlas Respubliki Bashkortostan [Atlas of the Republic of Bashkortostan]. Yaparov IM, editor. Ufa: Kitap Publ.; 2005. 420 p. In Russian

20. Reestr osobo okhranyaemykh prirodnykh territoriy Respubliki Bashkortostan [The list of specially protected natural areas of the Republic of Bashkortostan]. Mirkin BM, editor. Ufa: Gilem Publ.; 2006. 414 p. In Russian

21. O sostoyanii prirodnykh resursov i okruzhayushchey sredy Respubliki Bashkortostan v 2018 godu: Gosudarstvennyy doklad [On the state of natural resources and the environment of the Republic of Bashkortostan in 2018: State report]. Ufa: Ministerstvo prirodopol'zovaniya i ekologii Respubliki Bashkortostan; 2019. 276 p. In Russian

22. Baktybaeva ZB, Suleymanov RA, Valeev TK, Rakhmatullin NR. Evaluation of oil refining and petrochemical industry impact on environmental and hygienic state of environmental objects and population health (Literature review). Occupational Health and Human Ecology. 2018;4:12-26. In Russian

23. Kuramshin EM, Kuramshina NG, Nurtdinova EE, Imashev UB. Geokhimicheskaya otsenka zagryazneniya tyazhelymi metallami gorodskikh pochv bashkortostana [Geochemical assessment of heavy metal pollution urban soils of Bashkortostan]. Bashkirskii khimicheskii zhurnal = Bashkir Chemistry J. 2015;22(2):74-79. In Russian

24. Andreeva EN, Bakkal IYu, Gorshkov VV, Lyanguzova IV, Maznaya EA, Neshataev VYu, Stavrova NI, Yarmishko VT, Yarmishko MA. Metody izucheniya lesnykh soobshchestv [Methods for studying forest communities]. St. Petersburg: Research Institute of Chemistry of St. Petersburg State University Publ.; 2002. 240 p. In Russian

25. Forest Ecology and Conservation: A Handbook of Techniques. Newton A, editor. Oxford: University Press Publ.; 2007. 454 p.

26. Lesnye ekosistemy $i$ atmosfernoe zagryaznenie [Forest ecosystems and air pollution]. Alekseev VA, editor. Leningrad: Nauka Publ.; 1990. 200 p. In Russian

27. Root Methods: A Handbook. Smit AL, Bengough AG, Engels C, Noordwijk M van, Pellerin S and Geijn SC van de, editors. Berlin: Springer Publ.; 2000. 587 p.

28. Bargagli R. Trace Elements in Terrestrial Plants: An Ecophysiological Approach to Biomonitoring and Biorecovery. Berlin: Springer Publ.; 1998. 324 p.

29. Hill SJ, Fisher AS. Atomic Absorption, Methods and Instrumentation. Encyclopedia of Spectroscopy and Spectrometry. 3rd ed. Elsevier Publ.; 2017. pp. 37-43. doi: 10.1016/ B978-0-12-803224-4.00099-6 
30. Rademacher P. Atmospheric heavy metals and forest ecosystems: Work report of the Institute for World Forestry. Hamburg: Federal Research Centre for Forestry and Forest Products (BFH), Institute for World Forestry, 2003/12.

31. Seregin IV, Kozhevnikova AD. Roles of root and shoot tissues in transport and accumulation of cadmium, lead, nickel, and strontium. Russian Journal of Plant Physiology. 2008;55(1):122. doi: 10.1007/s11183-008-1001-8

32. Kabata-Pendias A. Trace Elements in Soils and Plants. 4th ed. Boca Raton: CRC Press/ Taylor \& Francis Group Publ.; 2010. 548 p.

33. Seregin IV, Ivanov VB. Physiological aspects of cadmium and lead toxic effects on higher plants. Russian J Plant Physiology. 2001;48(4):523-544. doi: 10.1023/A:1016719901147

34. Andresen E, Kupper H. Cadmium toxicity in plants. In: Cadmium: From Toxicity to Essentiality. Metal Ions in Life Sciences. Sigel A, Sigel H and Sigel RCO, editors. Netherlands: Springer Publ.; 2013;11:395-413.

35. Yusuf M, Fariduddin Q, Hayat S, Ahmad A. Nickel: An Overview of Uptake, Essentiality and Toxicity in Plants. Bulletin of Environmental Contamination and Toxicology. 2011;86(1):1-17. doi: 10.1007/s00128-010-0171-1

36. Sreekanth TVM, Nagajyothi PC, Lee KD, Prasad TNVKV. Occurrence, physiological responses and toxicity of nickel in plants. Int $J$ Environmental Science and Technology. 2013;10(5):1129-1140. doi: 10.1007/s13762-013-0245-9

37. Parlak KU. Effect of nickel on growth and biochemical characteristics of wheat (Triticum aestivum L.) seedlings. NJAS - Wageningen J Life Sciences. 2016;76:1-5. doi: 10.1016/j. njas.2012.07.001

38. Reeves RD, Baker AJM, Jaffré T, Erskine PD, Echevarria G, van der Ent A. A global database for plants that hyperaccumulate metal and metalloid trace elements. New Phytologist. 2018;218(2):407-411. doi: 10.1111/nph.14907

Received 28 May 2020; Revised 09 July and 17 August 2020; Accepted 03 September 2020; Published 25 September 2020

\section{Author info:}

Giniyatullin Rafak Kh, Dr. Sci. (Agr.), Senior Researcher, Laboratory of Forestry, Ufa Institute of Biology, Ufa Federal Research Centre of the Russian Academy of Sciences, 69 October Pr., Ufa 450054, Russian Federation.

ORCID iD: http://orcid.org/0000-0001-5729-3754

E-mail: grafak2012@yandex.ru

Baktybaeva Zulfiya B, Cand. Sci. (Biol.), Senior Researcher, Department of Medical Ecology, Ufa Research Institute of Occupational Health and Human Ecology, 94 S. Kuvykin Str., Ufa 450106, Russian Federation.

ORCID iD: http://orcid.org/0000-0003-1249-7328

E-mail: baktybaeva@mail.ru 